\title{
Report on the Pelagic Copepoda collected at Plymouth in 1888-89.
}

\author{
By \\ Gilbert C. Bourne, M.A., F.I.S., \\ Fellow of New College, Oxford, and Resident Director of the Association. \\ With Plates XI and XII.
}

Tне Copepoda not only form the greatest part of the pelagic life in temperate seas, but are also of the greatest importance in pelagic economy. Feeding on minute organisms and particles of animal and vegetable matter, they are themselves a prey to larger organisms. Some fishes such as the herring, pilchard, and mackerel feed almost exclusively on Copepoda at certain seasons of the year, and experienced fishermen are accustomed to look on the swarms of Copepods which make their appearance in the spring and early summer as the sure precursors of a shoal of fish. The important part played by these minute crustacea in the change of material in the sea has led me to pay particular attention to them amongst the other organisms found swimming free at the surface or at different depths in the open sea. The following is a preliminary account of the species which I have hitherto met with in the surface net collections made during the past year. The systematic work necessarily precedes the more laborious and thorough investigation of the life-history and bionomy of the group which I hope to be able to enter into at a later date, the present work, therefore, pretends to nothing more than an enumeration of the species captured, and an indication of their distribution. The species taken in the surface net amount to sixteen, of which the majority, as might be expected, belong to the Calanidæ. Of the sixteen, nine species belong to this family, two to the Cyclopidæ, three to the Harpactidæ, and two to the Corycæidæ. The majority are well known on British coasts, two species which I have found in abundance, viz. Paracalanus parvus and Euterpe gracilis, are generally considered rare in this country, and Pontella wollastoni is a rare English form which I have found sparingly. One species, Oncæa mediterranea, has not hitherto been seen north of the Mediterranean. On the other hand, several wellknown species of Calanidæ are altogether absent from my collections, viz. Metridia armata, Isias clavipes, and Centropages hamatus. The labour of looking through and sorting the large amount of material 
collected by us during the past year has been rery great, but I am satisfied that I have not allowed a species to escape my notice, and the above-mentioned forms must have been absent, during the past year at all events, from the open sea in this neighbourhood.

Having had access to only a limited number of systematic works on the Copepoda I am obliged to confine myself in the descriptive part of this paper to references to the following works. Brady's Monograph of the British Copepoda, three vols. Brady, Report on the Copepoda collected by H.M.S. Challenger, 1883. Claus, Die freilebenden Copepoden, 1863. Ibid, Neue Beitrage zur Kentniss der Copepoden, Arbeit aus dem. zool. Inst. Wien, 1880-81. Giesbrecht, Die freilebenden Copepoden der Kiele Foehrde. Vierter Bericht der Commission zur wiss. Untersuchung der deutschen Meere in Kiel, 1882. Canu, Les Copepodes libres Marins du Boulonnais, 1888. Thompson, Proceedings of the Liverpool Biological Society, vols. $\mathrm{i}$ and ii, 1887 and 1888.

\section{Family-CALANID无.}

\section{Cetochilus septentrionalis, Goodsir.}

Cetochinds helgolandicus, Claus. Die freilebenden Copepoden, p. 171, Taf. xxvi. Calanus finmarohicus, Brady. Monogr., i, p. 38.

$\begin{array}{lll}- & - & \text { Giesbrecht. Copepod. Kieler Foehrde, p. } 156 . \\ - & - & \text { I. C. Thompson. Proc. Liv. Biol. Soc., ii, p. } 63 .\end{array}$

This genus was found at all seasons of the year in the surface net, though seldom in considerable numbers, apparently it is more abundant towards the end of the autumn, but in the majority of gatherings it is altogether absent.

In adopting the generic name Cetochilus in preference to that of Calanus I am following the example of Claus, whose arguments in favour of retaining Roussel de Vauzeme's name for the genus appear to me to have more weight than the argument based on the uncertain identity of Müller's Cyclops longicornis with Gunner's Monoculus finmarchicus. For the discussion of the subject, vide Claus Neue Beitrage zur Kent. der Copep., Arb. Zool. Inst. Wien, iii, 3, and Brady, Challenger Reports, loc. cit.

2. Paracalanus parvus, Claus. Pl. XI, figs. $1-3$.

Calands parvus, Claus. Freilebenden Copepoden, p. 173, Taf. xxvi and xxvii.

Paracalands parvus, Claus. Neue Beitr. zur Kent. der Copep., Arb. Zool. Inst. Wien, iii, 3.

- $\quad$ - Canu. Copep. libres Marins du Boulonnais, Bull. Scient. de la France et de la Belg., iii sér., 1 ann., p. 81.

NEW SERIES.-VOL. I, NO. II. 
Paracalanus parves, I. C. Thompson. Copep. of Liverpool Bay, Proc. Liv. Biol. Soc., ii, p. 64 .

This species appears to have been taken only once before in England, viz. by the Liverpool Marine Biology Committee in 1888. Canu found it in abundance at Wimereux. I cannot consider it as a rare species at Plymouth for I have found it in great abundance in several gatherings and less abundantly in many others. Apparently it is absent from these coasts in the winter, for I could not find a single specimen in gatherings made between September and March. I have not observed the disproportion in the numbers of males and females described by Canu. This species is easily recognised by the form of the first antennæ of the male, by the serration of the external edges of the outer branches of the swimming feet, and their simple spines in both sexes, and by the characteristic shape of the fifth feet in the male and female. The characteristic ensiform and plumose terminal setæ of the second maxillipedes of the male appear to have been overlooked by previous observers, vide Pl. XI, fig. 3 .

\section{Cluadsia elongata, Boecl.}

Pseudodatands elongatus, Brady. Monogr., Brit. Copep., i, p. 45, pl. iii.

Giesbrecht. Freileb. Copep. der Kieler Foehrde, Nachtrag.

- $\quad-\quad$ I. C. Thompson. Proc. Liv. Biol. Soc., ii, p. 63.

Cladsia blongata, Claus. Neue Beitrage zur Kent. der Copep., Arb. Zool. Inst. Wien, iii, 3, p. 16, Taf. iii, figs. 11-15.

Luculuus Acusprs, Giesbrecht. Freileb. Copep. der Kieler Foehrde, p. 160.

This is one of the commonest species in the Plymouth district. I have taken it in autumn, winter, and spring in immense numbers. The absence of the fifth pair of feet in the female, and the form of the fifth feet of the male are characteristic features of this species. Young males are frequently very abundant, and as Claus has pointed out (loc. cit.), they differ from the perfect males both in the form of the fifth feet and in other particulars, so that they might easily be mistaken for a distinct species. Giesbrecht in the body of his work, quoted above, refers Clausia elongata to a new genus and species, Lucullus acuspes, but withdraws this name in an appendix. It is difficult to understand how he can have overlooked the identity of his specimens with Pseudocalanus elongatus, Boeck; described by Brady, since the latter's figures of the fifth pair of feet of the male are readily recognisable, defective as his description may be in some particulars. I. C. Thompson in a report of Copepoda collected in Maltese seas, refers to Lucullus acuspes, Giesbrecht; and Pseudo- 
calanus elongatus, Boeck, as distinct genera! ('Proc. Liv. Biol. Soc.,' ii, pp. 14.0, 142.)

4. Dias longiremis, Lilljeborg, Pl. XI, figs. 4-6.

Dias longrremis, Brady. Monogr. Brit. Copep., i, p. 51, pl. v.

- $\quad$ - Claus. Freileb. Copepod., p. 193, Taf. xxxiii, figs. 6-14.

- - - Giesbrecht. Freileb. Copep. der Kieler Foehrde, p. 148.

- $\quad$ - I. C. Thompson. Some Copepoda new to Britain, \&c., Proc.

Liv. Biol. Soc., i, p. 37.

This species is one of the most common near Plymouth. I have taken it in great quantities at all seasons of the year. Giesbrecht remarks that the genus Dias is found very sparingly at Kiel during the early spring months, but that it increases in numbers from July to the autumn. At Plymouth the contrary appears to be the case. On February 20th, 21st, and 22nd, 1889, the Calanidæ taken in the tow-net consisted almost exclusively of this species, and it was abundant in gatherings made both before and after these dates.

A close examination of these specimens leaves me in some doubt as to the distinctness of Giesbrecht's three species, $D$. longiremis, Lilljeborg; $D$. bifilosus, and $D$. discaudatus. According to him the remarkable differences (auffallende Merkmale) between $D$. longiremis and D. bifilosus are the presence of spines on the last thoracic segment of the former, and their absence in the latter species; the shape of the furca, which is much longer in D. longiremis than in D. bifilosus, and the presence of frontal setæ in the latter species. D. discaudatus is distinguished principally by the swollen furcal segments of the female and the spermatophores of the male, but in addition to these characteristics there are differences in the fifth pair of feet in the male (vide Giesbrect, loc. cit., Taf. viii, figs. 30,31 , and 32 ). In my specimens the spines characteristic of Dias longiremis are present, but are not so long as those figured by Giesbrecht; there are no frontal setæe and the feet of the fifth pair are precisely those figured by Giesbrecht for $D$. longiremis. The difference lies in the furcal segments, the proportions of which are those of D. bifilosus, Giesbrecht and not of $D$. longiremis. From his drawing of the fifth pair of feet of the male I have no doubt that Brady's figures are taken from $D$. longiremis, Lilljeborg, though he has overlooked the spines of the last thoracic and abdominal segments. Claus' figure of the fifth pair of feet of the male is undoubtedly taken from $D$. discaudatus, Giesbrecht (cf. Claus, Freileb. Copepod., Taf. xxxiii, fig. 14, and Giesbrecht, loc. cit., Taf. viii, fig. 32). At the same time Claus speaks of the frontal setæe characteristic of $D$. bifilosus. Giesbrecht considers that the varieties in the fifth pairs of feet of the 
males taken by Claus in Heligoland and the Mediterranean point to their being in fact two distinct species, but the facts given above support the conclusion that the characters taken by Giesbrecht as specific are liable to great variation, and that his three species, $D$. longiremis, $D$. bifilosus, and $D$. discaudatus are, in fact, varieties of one species, viz. Dias longiremis, Lilljeborg.

5. Temora longicornis, $O . F$. Müller.

Temora finmarchica, Claus. Freileb. Copepod., p. 195.

- Longrconnis, Brady. Monogr. Brit. Copep., i, p. 54.

- $\quad$ - Canu. Les Copep. libres marins du Boulonnais, Bull. Sci. de la France et Belg., iii sér., 1 ann., p. 89.

- $\quad$ - Giesbrecht. Freileb. Copep. der Kieler Foehrde, Nachtrag. HaLitemora longicornis, Giesbrecht. Ibid., p. 149.

I. C. Thompson. Proc. Liv. Biol. Soc., vol. i, p. 35.
I

This very common species was found sparingly during the winter months at Plymouth; its numbers increase greatly in April, and appear to reach a maximum in August and September. Thompson, in adopting the generic name Halitemora, overlooks Giesbrecht's appendix in which the latter gives way to the priority of Claus' name Temora (Claus, Sitz. der Kais. Akad. Wien, lxxiii, 1881.)

6. Centropages typicus, Kroyer.

ICthyophoRbA DENTICornis, Claus. Freileb. Copepod., p. 199, Taf. xxxv, figs. 1, 3-9.

Centropagrs typicus, Brady. Monogr. Brit. Copep., i, p. 65, pl. viii.

- Canu. Les Copepodes libres, \&c., Bull. Sci. de la France et de la Belg., iii sér., 1 ann., p. 96.

Taken in great abundance in summer, autumn, and spring, but it appears to be less abundant in the winter months.

7. Parapontella brevicornis, Lubbock.

Parapontelita brevicornis, Brady. Monogr. Brit. Copep., i, p. 69, pl. ix, figs.1-6. I. C. Thompson. Copep. Liv. Bay, Proc. Liv. Biol. Soc., ii, p. 65.

I have only found this species on two occasions, and then in small numbers, viz. on August 31st, 1888, near the Eddystone Lighthouse, and on March 21st, 1889, in the Cattewater. 
8. Pontella Wollastoni, Lubbock.

Pontelta hegqolandica, Claus. Freileb. Copepod., p. 208, Taf. iii, figs. 5-7; xxxvi, figs. $1-15$; xxxvii, fig. 7.

- Wollastoni, Brady. Monogr. Brit. Copep., i, p. 73, pl. x $a$.

- $\quad$ - Canu. Copep. libr. mar. du Boulonnais, Bull. Sci. de la

France et de la Belg., iii sér., 1 ann., p. 100.

- J. C. Thompson. Some Copep. new to Great Brit., Proc. Liv. Biol. Soc., i, p. 37.

I have only found this species twice, on August 31st, 1888, and on October 23rd, 1888, near the Eddystone Lighthouse, in small numbers in each instance. According to Thompson it is not uncommon in Liverpool Bay, and it is one of the commonest species at Wimereux (Canu).

9. Anomalocera Patersonir, Templeton.

Irenzus Patersonir, Claus. Freileb. Copep., p. 206, Taf. ii, fig. 1; Taf. xxxvii, figs. $1-6$.

Anomalockra Patersonit, Brady. Monogr. Brit. Copep, i, p. 75, pl, xi, figs. 1-14; pl. x, figs. 13,14 .

This species was abundant at Plymouth in the autumn and late summer but was absent from winter gatherings. I found a few specimens in the contents of the surface net on May 19th, 1889. Sometimes it occurs in immense profusion in the Channel. $\mathrm{Mr}$. Matthias Dunn has sent me a large number of Copepods, dipped with a bucket from Mevagissey Harbour. They consisted almost exclusively of A. Patersonii. In the specimens taken on May 19th I noticed that the upaired eye of the male was nearly half as large again as that of the female.

\section{Family-CYCLOPID A.}

1. Oithona spinirostris, Claus. Pl. XI, figs. 7 and 8.

Otthona helgolandioa, Claus. Freileb. Copep., p. 105, Taf. xi, figs. 4-9.

- spinirostris, Claus. Ibid., p. 105, Taf, xi, figs. 10-12.

- splnifrons, Brady. Monogr. Brit. Copep., i, p. 91, pl. xiv, fig. 19 ; pl. $x x i v a$.

- spininostris, Giesbrecht. Freileb. Copep. der Kieler Foehrde, p. 139.

- - I. C. Thompson. Proc. Liv. Biol. Soc., ii, pp. 1, 2.

This species is so rare as to be practically absent from Plymouth seas in the late summer and autumn, but it appears in great profusion in February, March, and April. Giesbrecht states that the same is the cuse at Kiel. According to the same author the different 
European species of Oithona are to be considered as varieties of $O$. spinirostris, Claus. The figures of Otthona in Brady's Monograph are very unsatisfactory, but those of 0 . Challengeri in the Challenger Report are much better. The only accurate drawings of Oithona that I have seen are those of Giesbrecht, whose illustrations never leave anything to be desired. As his work is not always accessible to English naturalists, I give, in Plate XI, figs. 7 and 8, drawings of the mandibles and maxillæ of this species.

\section{Cyclopina littoralis, Brady.}

Crclopina himtoratis, Brady. Monogr. Brit. Copep., i, p. 92, pl. xv, figs. 1-9. I. C. Thompson. Copep. Liv. Bay, Proc. Liv. Biol. Soc., ii, p. 65.

A few specimens of this well-marked species were taken in the tow-net in the early days of April, 1889.

$$
\text { Family-HARPACTID } \approx \text {. }
$$

1. Longipedia coronata, Claus.

Longipedia coronata, Claus. Freileb. Copep., p. 111, Taf. xiv, figs. 14-24.

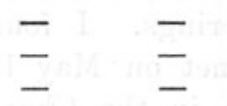
Brady. Monogr. Brit. Copep., ii, p. 6, pls. xxxiv, xxxv. Giesbrecht. Freileb. Copep. der Kieler Foehrde, p. 99. I. C. Thompson. Cop. Liv. Bay, Proc. Liv. Biol. Soc., ii, p. 67 .

A few specimens were taken in the surface net in March and April, 1889.

2. Euterpe gracilis, Claus.

Edtbrpe gracims, Claus. Freileb. Copep., p. 109, Taf. xiv, figs. 1-13.

- - Brady. Monogr. Brit. Copep., ii, p. 22, pl. xl, figs. 1-16.

- - I. C. Thompson. Copep. Liv. Bay, Proc. Liv. Biol. Soc., ii, p. 67 .

This species, rare in most localities, is very abundant near Plymouth in late winter and spring. I first found it on February 20th, 1889, when the tow-net taken near the Eddystone Lighthouse contained a profusion of females, nearly all carrying ovisacs. Since that date I have taken both males and females, sometimes sparingly, sometimes abundantly, in nearly every gathering up to May 20th.

3. Thalestris mysis, Claus.

Thalestris mysis, Claus. Freileb. Copep., p. 130, Taf. xviii, figs. 12-16.

- - Brady. Monogr. Brit. Copep., ii, p. 121, pl. lviii, figs. 1-13. 
Three or four specimens were taken in the surface net in the Cattewater on March 21st, 1889.

\section{Family-CORYCAIDA.}

1. Coryceus anglicus, Lubbock.

Corycaus germands, Claus. Freileb. Copep., p. 156, Taf. ix, figs. 1-4; Taf. xxiv, figs. 5, 6; Taf. xxviii, figs. 1-4.

- Anglicus, Brady. Monogr. Brit. Copep., iii, p. 34, pl. lxxxi, figs. 16-19; lxxxiii, figs. 11-15; lxxxiv, figs. $10-14$.

This species appears to be somewhat rare and locally distributed on British coasts. I first found a few in the tow-net of February 20th, near the Eddystone Lighthouse, and from that date up to May I obtained numerous specimens, scarcely any gathering being without them. It is recorded in my note-book that of the specimens taken February 21st, 22nd, and 23rd, 1889, all the females had ovisacs attached.

2. Oncean mediterranea, Claus. Pl. XII, figs. 1-7.

Antaria medrternanea, Claus. Freileb. Copep., p. 158, Taf. xxx, figs. $1-7$. Onces obtusa (?), Brady. Challenger Reports, Zoology, vol. viii, p. 120, pl. li. - - I. C. Thompson. Copep. collected in Maltese Seas, Proc. Liv, Biol. Soc., ii, p. 148.

I have much pleasure in recording this species, which has not before been found north of the Mediterranean. It is very rare at Plymouth. I have only had two specimens, one taken on the 31st August, 1888, the other on April 15th, 1889 ; both are females.

I am satisfied that my specimens are identical with Claus' Antaria mediterranea, but am not quite sure of their identity with Oncæa obtusa, Dana. Comparing my specimens with Claus' and Brady's figures, the second joint of the second antenna agrees in my specimens with Claus' drawing and description (zweite Glied der Klammerantennen aufgetrieben, dreieckig, so gross als die dritte), but in Brady's drawing it has not the characteristic swollen three-cornered shape. The furca in Brady's drawing is as long as the three preceding abdominal segments; in Claus' Antaria mediterranea and in my specimens it is but little longer than the last abdominal segment. The spines on the first abdominal segment of the male are longer in Claus' figures than in Brady's. From want of specimens I am unable to give an opinion on the specific distinctness of these two forms, but I have preferred to use Claus' specific name for my specimens because of their full agreement with his drawings and description. 


\section{PLATES XI AND XII.}

Illustrating Mr. G. C. Bourne's paper on The Pelagic Copepoda collected at Plymouth in 1888-89.

\section{PLATE XI.}

Fig. 1.-Paracalanus parvus. Third swimming foot.

Fig. 2.-Ibid. $\delta$. Fifth pair of feet.

FIG. 3.-Ibid. $\delta$. Second maxillipedes.

FIG. 4.-Dias longiremis. $\delta$. Fifth pair of feet.

FrG. 5.- - Did. Last thoracic and first two abdominal segments of $q$ showing the spines.

Frg. 6.-Ibid. Furcal segments of $\delta$.

FIG. 7.-Oithona spinirostris. Maxilla.

Fra. 8.-Ibid. Mandible.

\section{PLATE XII.}

Oncaa Mediterranea. $\quad$.

FIG. 1.-First antenna.

FrG. 2.-One of the swimming feet.

FIG. 3.-Second maxillipede.

Frg. 4.-Maxilla.

FIG. 5.-Abdominal segments.

FIG. 6.-First maxillipede.

FIG. 7.-Second antenna. 
Jour. Mar. Biol. Assoc. Vol. I, Pt II.

Plate XI.

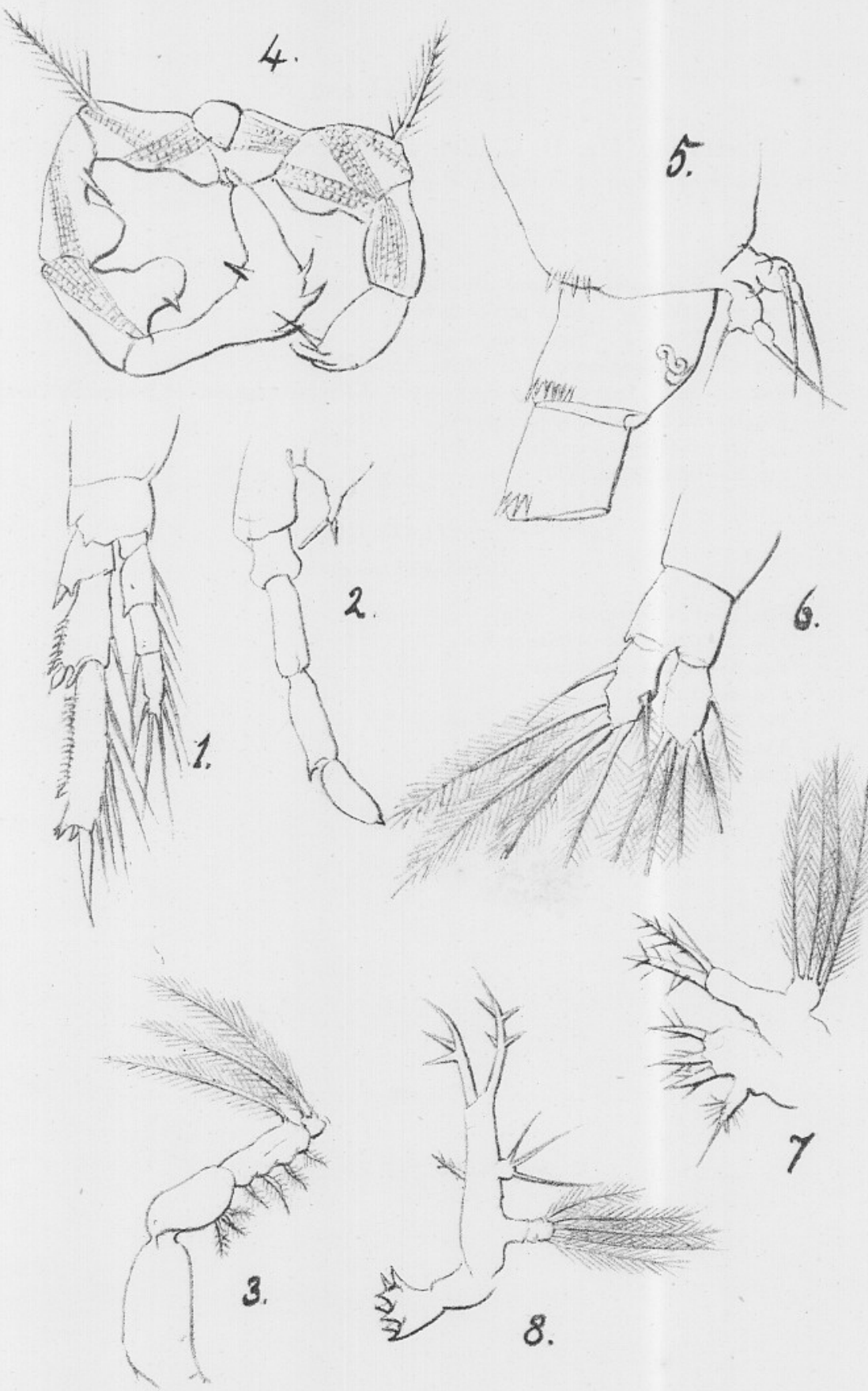

Gesormus 


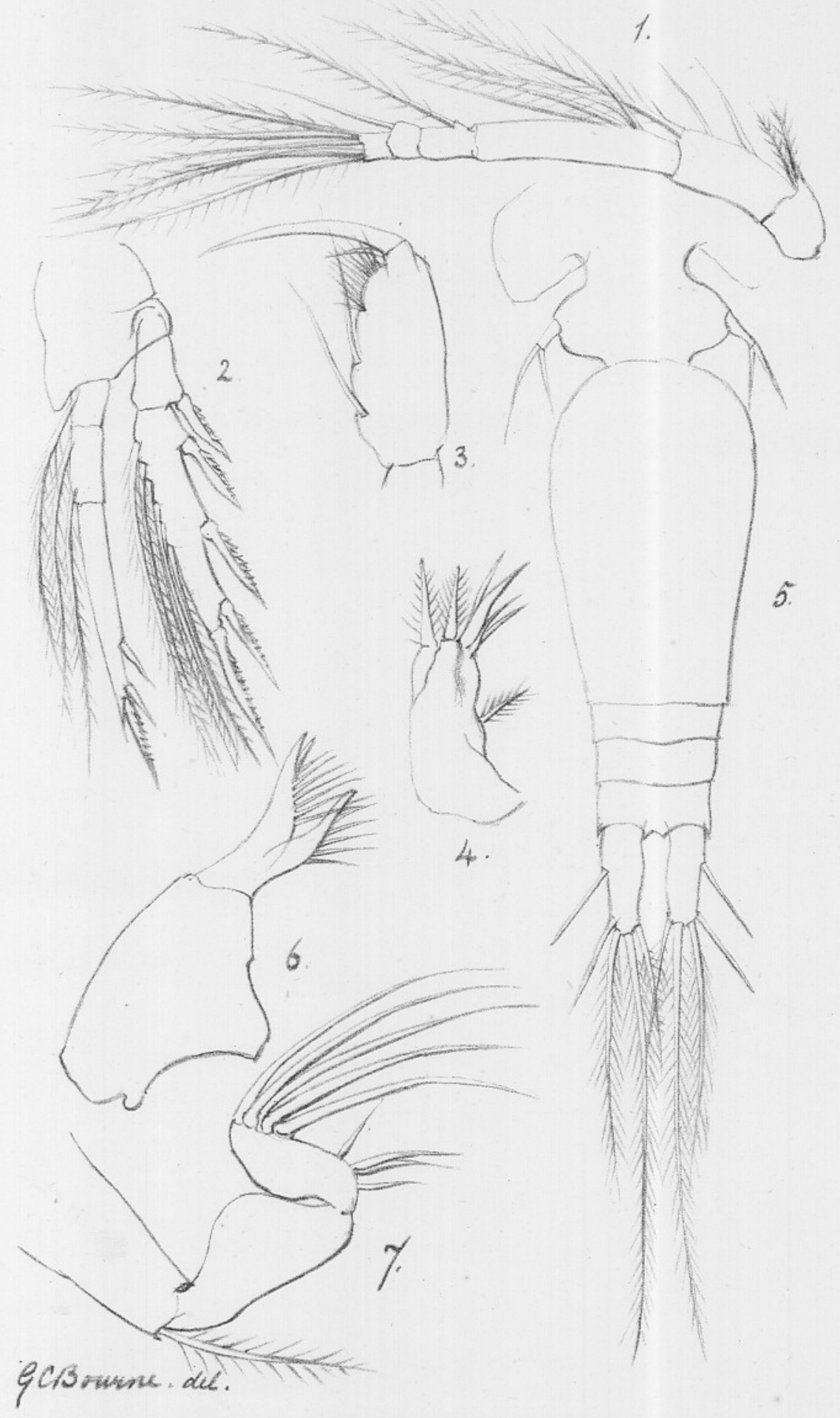

